\title{
Investigation of Organizational Citizenship Behavior of Hotel Employees by Structural Equation Model
}

\author{
Eren Erkiliç¹, Ali Çağlar Güllüce ${ }^{2}$ \\ ${ }^{1}$ Ardeşen Vocational School, Recep Tayyip Erdogan University, Rize, Turkey \\ ${ }^{2}$ Open Education Faculty, Atatürk University, Erzurum, Turkey \\ Email: eren.erkilic@erdogan.edu.tr, alichaglar@y ahoo.com
}

How to cite this paper: Erkiliç, E. and Güllüce, A.Ç. (2017) Investigation of Organizational Citizenship Behavior of Hotel Employees by Structural Equation Model. iBusiness, 9, 31-47.

https://doi.org/10.4236/ib.2017.92003

Received: May 26, 2017

Accepted: June 23, 2017

Published: June 26, 2017

Copyright $\odot 2017$ by authors and Scientific Research Publishing Inc. This work is licensed under the Creative Commons Attribution International License (CC BY 4.0).

http://creativecommons.org/licenses/by/4.0/

\begin{abstract}
The aim of this study is to determine the level of organizational citizenship behavior of the employees in the hotel businesses operating in the province of Rize in the Black Sea Region of Turkey. For this purpose, 345 questionnaires were applied to the employees in question. The obtained data were analyzed through LISREL and SPSS programs. As a result of confirmatory factor analysis which was performed to determine the organizational citizenship behaviors of the participants, it was found out that there are significant positive relationships among organizational citizenship behavior factors. In this context, the most effective variable on the altruism factor was found to be "I do not hesitate to share the materials with my co-workers in the case of job related problems." with a ratio of 0.99 . One the most effective variables on the conscientiousness factor was detected as "I spend most of my time in business related activities" with a ratio of 0.94 . On the other hand, "I warn other employees not to be hurt when unexpected problems occur" variable with a ratio of 0.95 was determined on the courtesy factor. It was also figured out on the sportsmanship factor that "I do not my waste time complaining about minor problems." variable has ratio of 0.89 . "I keep up with the changes made in the structure of the organization I work with." variable is influential with a ratio of 0.95 on the Civic Virtue factor. In addition, it was revealed that conscientiousness and sportsmanship factors have an effect between each other with a ratio of 0.53 .
\end{abstract}

\section{Keywords}

Organizational Citizenship, Hotel Employees, Structural Equation Model 


\section{Introduction}

Organizations have come to show a behavior ahead of their business structure and nowadays have become more dependent on employees that contribute most to organizational performance. As a matter of fact, doing business under new economic conditions has become an important feature of understanding. In this context, behaviors that are outside the business requirements and which enable organizations to maintain their assets are at the forefront. These behaviors are considered in the literature as the concept of organizational citizenship behavior [1].

Organizational citizenship behavior is not directly involved in the rewards system. However, it is indicated that when it is taken as a whole, helping to fulfill organizational functions effectively and efficiently; and it is the behavior based on volunteerism. These behaviors are compulsory and if they do not perform together, they do not require punishment and are personally preferred behaviors [2]. When researches realized up to the 1980s are examined, it is seen that the concept of organizational citizenship behavior was not studied as a single subject. However, the studies executed on organizations in the past years have included the concepts that may form the basis for future work on organizational citizenship behaviors. These behaviors which are called prosocial organizational behaviors, are a comprehensive concept that includes organizational citizenship behaviors [3].

Citizenship is synonymous with the word countryman and defined as "being born or grown up in a country or living there, being a person from that country, belonging with that country" [4]. The concept of organizational citizenship behavior is described by George and Brief [5] as the behaviors that are within or beyond the employee's role descriptions and are outside the formal reward system. Greenberg and Baron have described the concept of organizational citizenship as "making an employee want to do more than is necessary, beyond the requirements that the organization has to shape in a formal way" [6]. Abu Tayeh [7] defined organizational citizenship behavior as "a voluntary behavior of an employee without expecting any reward or financial incentive to promote the organization". It has been characterized as an internal sense of responsibility that motivates the individual to volunteer work in order for achieving goals of the organization. According to Organ [8], three dimensions in the definitions of organizational citizenship behavior should be noted:

- The emergence of organizational citizenship behavior depends on the person and rewarding is not provided, and it is not punished when this behavior is not performed.

- Organizational citizenship behavior does not take place directly or indirectly within the employee's work.

- No training is taken during the demonstration of organizational citizenship behavior as it is wanted by the person and organizational citizenship behavior enhances the functionality of the organization. 
As a result of that, Organ [8] defines the organizational citizenship behavior as "individual behavior that is discretionary, not directly or explicitly recognized by the formal reward system and that in the aggregate promotes the effective functioning of the organization". This definition of OCB includes three critical aspects that are central to this construct. First, OCBs are considered as discretionary behaviors, which are not part of the job description, and are carried out by the employee as a result of personal choice. Second, OCBs go above and beyond that, which is an enforceable requirement of the job description. Finally, OCBs contribute positively to overall organizational effectiveness.

Afore mentioned before, organizational citizenship behavior is the volunteer behaviors of employees. The tourism sector is one of the key sectors in the country economy that provides employment. We should emphasize that hotel enterprises are also the enterprises which are in the tourism sector and serve on the basis of human power. Hotel establishments are regarded as the organizations in which organizational citizenship behavior is exhibited. In this context, because of the structure of the tourism sector, it can be said that employees must demonstrate extra role behaviors ahead of their duties for the hotel business to work under the tough and necessary conditions. Such behaviors are also viewed as organizational citizenship behaviors in businesses [9].

When the literature is examined, it observed that the dimensions of organizational citizenship behaviors have not been fully clarified and no consensus has been reached on this issue [10] [11] [12] and Different classifications have emerged. The accepted and most used classification is the classification made by the Organ [8] [13]. Organ [8] stated the organizational citizenship behavior in five different dimensions as Altruism, Conscientiousness, Courtesy, Sportsmanship and Civic Virtue [14]. Since the most frequently used classification in the literature is the dimension of organizational citizenship behavior by Organ [8], these five dimensions have been examined in this study. According to Organ, organizational citizenship behaviors are as follows [15]:

- (Altruism)

- (Courtesy)

- (Conscientiousness)

- (Sportsmanship)

- (Civic Virtue)

(Altruism): Altruism expresses all the volunteer behavior of the employees to help other employees working within organizations [8]. Altruism dimension includes activities to help and support employees in their work related problems. Generally, it covers the individual behaviors and influences the organizational performance positively so that it increases organizational effectiveness [16]. In a case when one of his colleagues has fallen ill and cannot come to work, undertaking his work can be given as an example for the dimension of thinking of others [17].

(Conscientiousness): Conscientiousness means the voluntary behaviors of employees who, in accordance with the rules and regulations, work within the 
required breaks, beyond the minimum jobs [18]. These behaviors can be expressed as behavior coming to work before the due time, not leaving the workplace until the job is completely done, not giving unnecessary breaks, protecting resources and offering constructive suggestions [19].

(Courtesy): Courtesy can be expressed as voluntary behavior in terms of preventing business related problems before they arise [20]. DiPaola and Hoy [16] stated that courtesy includes behaviors like informing, reminding, sharing useful information and avoiding problems by transferring information and using the facilities efficiently with time. Organ [8] stated that the courtesy dimension is associated with communication in organizations. Some of the examples of courtesy could be; "employees" being in communication due to their duties, informing employees in advance due to the taken decisions and previously done work, explaining necessary situations and transmitting information" [21].

(Sportsmanship): Organ [8] defines sportsmanship as the way that the employees endure the difficulties and negative aspects of work without making complaint. In other words, it is a state in which employees do what they are asked by the organization without showing any sensitivity when employees are disturbed by other employees or circumstances do not go in the desired condition [22]. Özdevecioğlu [23] explains sportsmanship as the situation in which the employees in the working environment ignore adverse situations [23]. Sportsmanship behavior includes behaviors like avoiding stress and tension-causing behaviors instead of concentrating on problems, showing patience and supporting the effectiveness and efficiency of the organization. It is seen that management resources are used to solve the negative situations in organizations. But instead of dealing with problems in organizations where gentlemanly behavior is identified, resources are transferred to applications such as planning, problem solving and organizational analysis, and organizational efficiency is ensured [24].

(Civic Virtue): Civic Virtue dimension involves behaviors such as participation in all activities carried out within the organization, observing threats and opportunities that may arise. This dimension concerns the development of interest and contribution in the organization by participating in the rules and in the activities in the procedures that exist within the organizations [16] [25]. It also means that employees want to participate in activities that help their organization to develop, achieve its goals and objectives, and participate in activities that will help the organization's image, even if it is not among employee's tasks. Some of the examples of civic virtue could be; "to keep up with the developments in the organization, to adapt and to keep up with these changes, to accept these mentioned changes" [26].

\section{Material Method}

\section{Structural Equation Modeling}

The Structural Equation Modeling (SEM) applications that have been increa- 
singly prevalent in the social sciences and behavioral sciences in recent years have become an indispensable part of a large number of scientific research initiatives. SEM, which can now easily be called as a research method in its own right, provides a variety of advantages with the researchers [27].

Analysis of latent variables used mainly in psychological studies is related to the disclosure of unobservable structs. Hence, latent variables play a fundamental role in explaining the structure of psychological theory. Today, this concept is associated with SEM, is widely discussed and used. This situation, which is based on the science of psychology, is widely used in many studies such as in biology, in ecological research, in explaining the movements of electrons, in marketing research, in information technology, artificial neural networks, and biometric studies [28].

SEM contains one or more linear regression equations describing how the inner structs are connected to the outer structs. Coefficients are called as path coefficients or often regression weights. When SEM modeling is performed, the following steps are taken [29] [30] [31].

1) To develop a theoretical model,

2) To draw the diagram showing the causal relationships for the developed model,

3) To convert the plotted diagram into structural and measurement models,

4) To Estimate and evaluate the structural model,

5) To calculate the eligibility criteria of the structural model,

6) Interpret the results.

The packet programs used in SEM analysis give different numbers of fit indices; sometimes the same index is given a different name. LISREL users often interpret the results according to fit indices such as GFI, AGFI, RMSEA, CFI and NNFI, along with Chi Square value [30].

\section{Application}

The population of the study is formed of employees working in the hotel enterprises operating in Rize. According to Culture and Tourism Directorate Office in Rize [32], as of 2016, there were a total of 70 accommodation facilities including 11 certified tourism facilities (one 4 star, six 3 star and four 2 star facilities), 14 public institution facilities and 45 other accommodation facilities.

To measure the organizational citizenship behaviors of hotel employees in Rize, the scale that was used prepared by Basımve Şeşen [33] adopted from the study by Vey/Campbell [34] and Williams/Shiaw [35]. The questionnaire consisted of five dimensions and was stated that it was consistent with the dimensions of organizational citizenship behavior revealed by Organ [8]. A total of 19 questions (5 items on Altruism, 3 items on Courtesy, 3 items on Conscientiousness, 4 items on Sportsmanship, 4 items on Civic Virtue) are included in this questionnaire to measure dimensions of organizational citizenship behavior scale. 
As seen in Table 1, according to the 1989 research by Ministry of Tourism named as "Labor and Tourism in the Hotel and Tourism Sector", The number of staff per room over the general average was calculated as 0.70 while the number of personnel per bed on the overall average was calculated as 0.35.

According to Rize Provincial Directorate of Culture and Tourism [32], the accommodation facilities in Rize have a total number of 1876 rooms and a capacity of 3895 beds. The averages in Table 1 was predicated on, and when the number of personnel was calculated according to the number of rooms in Rize $(1876 \times 0.70) 1313.2$ personnel, whereas the number of personnel is calculated according to the number of beds $(3895 \times 0.35), 1363.25$ personnel results were achieved.

According to the gained results, it was agreed to calculate the population of the study according to the number of personnel per bed so 1363 hotel employees were considered the population of the study.

The prepared questionnaire was applied randomly to 450 employees among the hotel employees working in Rize between 20 April 2016 and 1 June 2016. The Sample size was calculated by the formula suggested by Özdamar [38] for unbounded population $(\mathrm{N}>10,000)$ and recommended for quantitative studies $n=\sigma^{2} Z_{\alpha}^{2} / H^{2}$. Each item that constituted the scale was graded on a Likert scale of five, and the items were rated as " $1=$ Strongly Disagree", " $2=$ Disagree", " $3=$ Neither Agree nor Disagree", “ $4=$ Agree”, " 5 = Strongly Agree”. After the inaccurate and incomplete questionnaire forms were removed, the analyzes were carried out through 345 valid questionnaire forms.

For the each item in the questionnaire used, the reliability coefficient Cronbach's Alpha value was calculated as 0.885 .

Table 1. Number of personnel per bed and room in accommodation businesses in $\mathrm{Tu}$ rkey.

\begin{tabular}{ccc}
\hline Business Types & Number of Staff per Room & Number of Staff per Bed \\
\hline 5 Star Hotel & 1.18 & 0.59 \\
4 Star Hotel & 0.76 & 0.38 \\
3 Star Hotel & 0.72 & 0.36 \\
2 Star Hotel & 0.56 & 0.28 \\
1 Star Hotel & 0.50 & 0.25 \\
Specifically Certified & 1.48 & 0.74 \\
HolidayVillage & 0.74 & 0.37 \\
1st Class Motel & 0.74 & 0.37 \\
2nd Class Motel & 0.94 & 0.47 \\
B and B and Oberj & 0.40 & 0.20 \\
TOTAL AVERAGE & $\mathbf{0 . 7 0}$ & $\mathbf{0 . 3 5}$ \\
\hline
\end{tabular}

Source: Ministry of Tourism [36], Ağaoğlu [37]. 
When Table 2 was examined, it is clear that 135 of the 345 participants were women and 210 were male. Female employees constitute $39.1 \%$ of the group while male employees constitute $60.9 \%$. When this study was examined by age groups, it was found that 40 participants (11.6\%) were 20 years old or below, 102 participants (29.6\%) were between 21 - 25 years, 78 participants (22.6\%) were between 26 - 30 years and 125 participants (36.2\%) were 31 years or more, respectively. Percentage and frequency distributions of participants' marital status were given. According to that, it was detected $53.0 \%$ of the participants were single $(f=183), 45.5 \%$ were married $(f=157)$ and $1.4 \%$ were other $(f=5)$ (widow, divorced). When the distribution of educational status is examined, it is observed that the majority of participants are high school and university graduates. The participants at the primary school level were 55 people (15.9\%) while 142 participants (41.2\%) were high school graduates. 140 participants were $(40.6 \%)$ university graduates and 8 of them $(2.3 \%)$ were at the post-graduate level. Among the participants, 118 (34.7\%) were in the food and beverage department, $106(30.7 \%)$ were in the front office department, 71 (20.6\%) were in the housekeeping department, 30 (8.7\%) were in the sales and marketing department and 20 (5.8\%) were in accounting department. According to distribution by position variable, $9.3 \%(f=32)$ was department manager, $3.5 \%$ was $(f=12)$ department vice manager, $13.0 \%(f=45)$ was chief and $74.2 \%(f=256)$, which made the majority, was the employees. When the experience of the participants

Table2. Demographic characteristics of hotel employees.

\begin{tabular}{|c|c|c|c|c|c|c|c|}
\hline Variable & Group & f & $\%$ & Variable & Group & f & $\%$ \\
\hline \multirow{2}{*}{ Gender } & Female & 135 & 39.1 & \multirow{6}{*}{ Department } & Front Office & 106 & 30.7 \\
\hline & Male & 210 & 60.9 & & Food and drink & 118 & 34.2 \\
\hline \multirow{4}{*}{ Age } & 20 and below & 40 & 11.6 & & Housekeeping & 71 & 20.6 \\
\hline & Between $21-25$ & 102 & 29.6 & & Sales and marketing & 30 & 8.7 \\
\hline & Between 26- 30 & 78 & 22.6 & & Accounting & 20 & 5.8 \\
\hline & 31 and more & 125 & 36.2 & & Employee & 256 & 74.2 \\
\hline \multirow{3}{*}{$\begin{array}{c}\text { Marital } \\
\text { Status }\end{array}$} & Married & 183 & 53.0 & \multirow{3}{*}{ Position } & Chief & 45 & 13.0 \\
\hline & Single & 157 & 45.5 & & Department Vice Manager & 12 & 3.5 \\
\hline & Other & 5 & 1.5 & & Department Manager & 32 & 9.3 \\
\hline \multirow{4}{*}{$\begin{array}{c}\text { Educational } \\
\text { Level }\end{array}$} & Primary & 55 & 15.9 & \multirow{4}{*}{$\begin{array}{l}\text { Experience } \\
\text { in Business }\end{array}$} & Less than 1 year & 110 & 31.9 \\
\hline & High School & 142 & 41.2 & & Between 1 - 5 years & 142 & 41.2 \\
\hline & University & 140 & 40.6 & & Between 6 - 10 years & 49 & 14.2 \\
\hline & Post-Graduate & 8 & 2.3 & & More than 10 years & 44 & 12.8 \\
\hline \multirow{4}{*}{$\begin{array}{l}\text { Experience in } \\
\text { Sector }\end{array}$} & Less than 1 year & 66 & 19.1 & & & & \\
\hline & Between 1 - 5 years & 114 & 33.0 & & & & \\
\hline & Between 6 - 10 years & 59 & 17.1 & & & & \\
\hline & More than 10 years & 106 & 30.7 & & & & \\
\hline
\end{tabular}


in the business is examined, it was concluded that the participants who worked in the business less than 1 year was 110 employees (31.9\%) while 142 employees (41.2\%) worked in the business between 1 - 5 years. On the other hand, the employees who worked in the business between 6 - 10 years were found to be 49 people $(14.2 \%)$ while 44 employees $(12.8 \%)$ stated that they have been working for the business more than 10 years. $19.1 \%(f=66)$ of participants have worked in the tourism sector less than 1 year and $33.0 \%(\mathrm{f}=114)$ of the employees have worked between 1 - 5 years. Additionally, 17.1\% ( $f=59)$ of the employees have worked between 6 - 10 years and 30.7\% = 106) have been working in the tourism sector for over 10 years.

Figure 1 shows the five factors in the organizational citizenship behavior in scale and the relationship between variables and the relationships of the factors between each other. When Figure 1 is examined, it is seen that VD represents the "Altruism" dimension of organizational citizenship behavior, VV "Conscientiousness", VN "Courtesy", VC "sportsmanship" and VS represents "Civil Virtue" dimension. In addition, VD1, VD2, VD3, VD4, VD5 represent the variables of the Altruism dimension; VV6, VV7, VV8 represent the variables of the Conscientiousness dimension; VN9, VN10, VN11 represent the variables of the Courtesy dimension, VC12, VC13, VC14, VC15 represent the variables of the sportsmanship dimension and VS16, VS17, VS18, VS19 represent the variables of the Civil Virtue dimension.

In this context, VD1 "I do the work of an employee who has taken a day's leave" variable has positively been influential on the Altruism dimension with a rate of 0.71 by one unit increase. One unit increase in VD2 "I help a worker who is dealing with extreme workload" variable has positively been influential on the Altruism dimension with a rate of 0.97. Also, one unit increase in VD4 "I do not hesitate to share the materials with my co-workers to eliminate the job-related

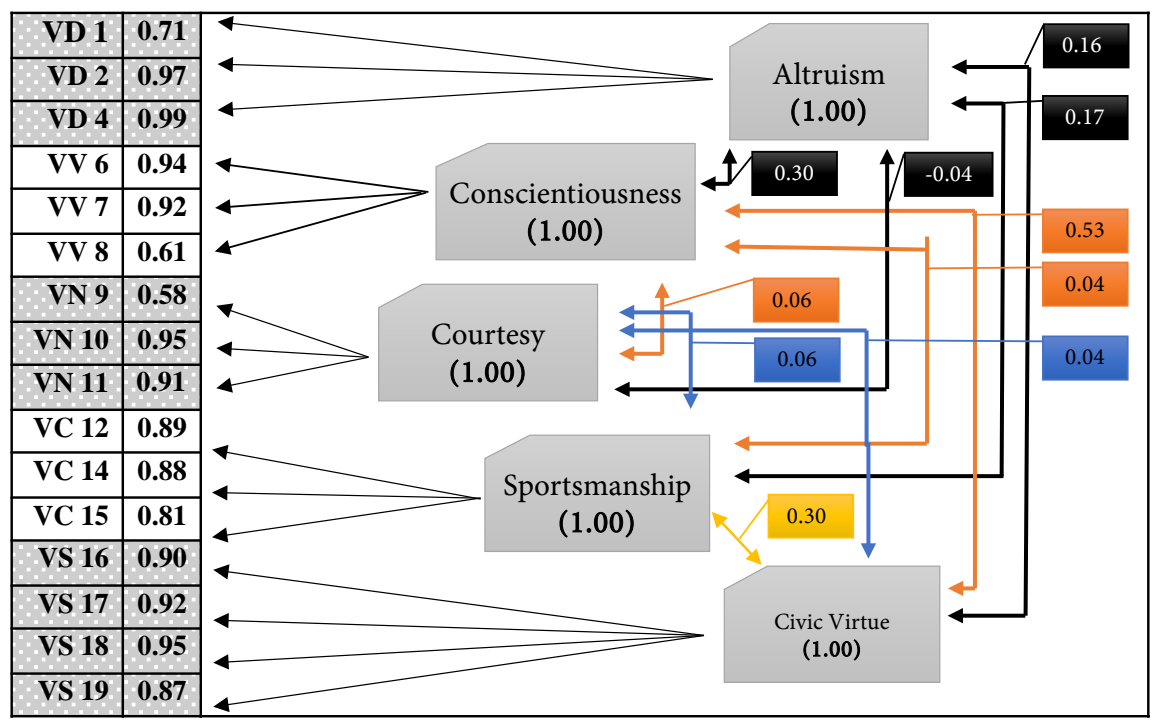

Figure 1. Organizational citizenship behavior and structural equation model of sub-dimensions $($ Chi-Square $=273.16, \mathrm{df}=92, \mathrm{P}$-value $=0.00000, \mathrm{RMSEA}=0.076$ ). 
problems" variable has positively been influential on the Altruism dimension with a rate of 0.99 .

On the other hand, VV6 "I spend most of my time in business related activities" variable has positively been influential on the Conscientiousness dimension with a rate of 0.94 by one unit increase. Also, the VV7 "I would like to participate in all the activities that will create a positive image for the institution I work for" variable has positively been influential on the Conscientiousness dimension with a rate of 0.92 by one unit increase. Additionally, VV8 "I do not spend time for my personal affairs during overtime period" variable has positively been influential on the Conscientiousness dimension with a rate of 0.61 by one unit increase.

As you can see in Figure 1, VN9 variable "I respect other people's rights and law" in courtesy dimension has been influential with a rate of 0.58 . VN10 variable "when unexpected problems occur, I warn other employees not to be harmed" has been rated as 0.95 while VN11 variable "I try my best not to create problems for other employees I work with" was found to be effective as 0.91 .

When the sportsmanship dimension of organizational citizenship behavior is examined, it was detected that VC12 "I do not waste time complaining about minor problems" variable has positively been influential on the sportsmanship dimension with a rate of 0.89 by one unit increase (Table 3 ). Besides, one unit increase in VC14 "I do not feel embarrassed or resentful about new situations I have experienced at work" variable has a positive influence on the sportsmanship dimension with a rate of 0.88 and $\mathrm{VC} 15$ "I take an active role in the resolution of the conflicts within the institution I work with" variable has made positive influence on the sportsmanship dimension with a rate of 0.81 by one unit increase.

On the other hand, the variable of VS16 "I read the announcements, messages, procedures, and short notes published by the top management and keep them where I can reach them" has positively been influential on the civic virtue (VS) dimension with a rate of 0.90 by one unit increase. Also, the variable of VS17 "I voluntarily take part in the social activities of the organization I work for" was found to be positively influential on the civic virtue (VS) dimension with a rate

Table 3. Values of compliance criteria for the established model.

\begin{tabular}{|c|c|c|c|}
\hline $\begin{array}{c}\text { Goodness of Fit } \\
\text { Criteria }\end{array}$ & Perfect Fit & Acceptable F1t & Model \\
\hline RMSEA & $0<$ RMSEA $<0.05$ & $0.05 \leq \mathrm{RMSEA} \leq 0.10$ & 0.07 \\
\hline NFI & $0.95 \leq \mathrm{NFI} \leq 1$ & $0.90<\mathrm{NFI} \leq 0.95$ & 0.95 \\
\hline NNFI & $0.97 \leq \mathrm{NNFI} \leq 1$ & $0.95 \leq \mathrm{NNFI} \leq 0.97$ & 0.95 \\
\hline CFI & $0.97 \leq \mathrm{CFI} \leq 1$ & $0.95 \leq \mathrm{CFI} \leq 0.97$ & 0.96 \\
\hline GFI & $0.95 \leq \mathrm{GFI} \leq 1$ & $0.90 \leq \mathrm{GFI} \leq 0.95$ & 0.91 \\
\hline AGFI & $0.90 \leq \mathrm{AGFI} \leq 1$ & $0.85 \leq \mathrm{AGFI} \leq 0.90$ & 0.87 \\
\hline
\end{tabular}


of 0.92 by one unit increase while the variable of VS18 "I keep up with the changes made in the structure of the organization I work for" was found to be positively influential with a rate of 0.95 . In addition, the variable of VS19 "I take part in research and project groups that perform all kinds of developing activities" has made positive impact on the civic virtue (VS) dimension with a rate of 0.87 by one unit increase.

When the relationship between the dimensions of organizational citizenship behavior is examined, it is indicated that in the relationship between the altruism (VD) dimension and (VV) conscientiousness dimension one unit of increase in both dimensions has a positive effect with a ratio of 0.30 . On the other hand, as the relationship between the dimensions the altruism (VD) and the courtesy $(\mathrm{VN})$ is investigated, it is noticed that one unit of increase in both dimensions has a negative effect with a ratio of -0.04 . As the relationship between the dimensions the altruism (VD) and the sportsmanship (VC) is studied, it is understood that one unit of increase in both dimensions has a positive effect with a ratio of 0.17 . Lastly, the relationship between the altruism (VD) dimension and civic virtue (VS) shows that one unit of increase in both dimensions has a positive effect with a ratio of 0.016 .

As we go through the relationship between conscientiousness (VV) and courtesy $(\mathrm{VN})$ dimensions, it is seen that one unit of increase in both dimensions has a positive effect with ratio of 0.06 while the relationship between conscientiousness (VV) and sportsmanship is studied; it was found out that it has a positive effect with ratio of 0.04 . Finally, when the relationship between conscientiousness (VV) and civic virtue is investigated, it seems that it has a positive effect with ratio of 0.53 . In this context, regarding the dimension of conscientiousness, it can be said that organizational citizenship behavior is positively influential on the other dimensions since the employees spend most of their time in business-related activities; they want to participate in activities that will create a positive image for the organization they work with and do not spend time on their jobs during business hours.

Once the relationship between courtesy (VN) and sportsmanship (VC) dimensions are examined, it is seen that one unit of increase in both dimensions has a positive effect between the two dimensions with a 0.06 ratio and has a positive effect on the civic virtue dimension (VS) with a 0.04 ratio. Finally, as (VC) the relationship between sportsmanship (VC) and civic virtue (VS) is studied, it can be noted that one unit of increase in both dimensions has a positive effect between the two dimensions with a 0.30 ratio.

In the study by Sökmenve Boylu [39], it was found out that especially the effect related to the Conscientiousness dimension was higher. In hotel businesses where the study was conducted, employees were sensitive about continuity, regularity and punctuality and developed positive attitudes. However, in this study, not spending time on private affairs during business hours, participating in activities to be performed on behalf of the institution will make the employee feel himself or the business honored. In a research by Alioğulları [40], the effect of 
the variables of "I respect my colleagues" and "I do not create problems for my colleagues" in the courtesy dimension were found to be high, and it was revealed that employees influence their colleagues' business considerations and being in harmony with them. It is possible to say that the expressions like hotel business employees respect each other's rights and be guiding and sacrificing have been influential in the courtesy dimension. In the study of Karaaslan, Ergun Özler and Kulaklığlu [41] stated that, behavioral examples within the scope of sportsmanship dimension, some behaviors such as keep up offering positive suggestions without being hurt to those who do not support employees' personal ideas and suggestions and who react against them could be evaluated as to evaluate information sharing behavior.

According to the results above, it can be interpret that employees are aware of the situations by expressing that they will not waste their time on minor problems; they will want to see the positive aspects of the problems, not the negative ones and they want to take an active role in resolving conflicts. In the study of Kalkan [42], the variable of "I keep pace with the business related developments" in the civic virtue was found to be with the highest average value while the variable of "I keep up with the changes made in the structure of the organization I work with" was detected as the most effective dimension in the civic virtue dimension. Hotel establishments have to stand out from the competition in respect to developing modern management approaches and technology so that these labor-intensive hotel establishments should first ensure the participation and acceptance of employees. Aksoy [43] studied the dimensions of organizational citizenship behaviors separately and found that the majority of employees had a tendency to show organizational citizenship behavior. Baran [44] asserted that organizational citizenship behavior is mainly based on the voluntary participation of members and Waris [45] set forth that organizational citizenship behaviors take place without an official request. Aras [46] exerted that these behaviors are behaviors that are not included in the duty and job descriptions of the employees and do not require punishment in case of negligence along with requiring more personal preference.

In this study, when the relationship between the Altruism dimension and the other dimensions is examined, it is seen that the Altruism dimension has been positively effective on all other dimensions. Therefore, it can be said that the behavior of organizational citizenship has a positive effect on other dimensions in some situation such as performing the work of an employee when this employee has taken a day's leave, sharing the material that you have with others, helping the ones who face some job-related problems. In addition, these employees in our study voluntarily contribute to this situation, which is consistent with the previously actualized studies. As demonstrated in the study by Organ [8], it was concluded that organizational citizenship behavior is not directly and completely taken into account in the stylistic system but is an individual behavior based on volunteerism that helps to increase organizational effectiveness as a whole. In their research on hospital employees by İşsever, Söyük and Şengün et al. [47], it 
was concluded that the participants exhibited organizational citizenship behaviors and found out that there are significant differences between participants' demographic characteristics and organizational citizenship behavior. In the research by Ugurlu and Demir [48] on their teachers, it was found out that the organizational citizenship behaviors of the participants were high. According to the research conducted by Yilmaz et al. [31] on teachers, In terms of general organizational citizenship behavior, female teachers compared to male teachers, teachers with 11 years and more seniority compared to teachers with 10 years or less seniority and class teachers compared to branch teachers exhibit more organizational citizenship behavior. In the research by Ipek and Sakli [49] on public employees in the tea sector, it was indicated that the organizational citizenship behaviors of the participants were moderate. In the research by Özdevecioglu [23] on university students, it was figured out that there is a significant difference between the demographic characteristics of participants and organizational citizenship behavior. As you can see, it was ended that our study, exploring the relationship between organizational citizenship behavior and its factors, seems to support the previous studies on organizational citizenship behavior.

\section{Conclusions}

It is important to make the best use of the resources and facilities they have in order to achieve the aims and objectives of the enterprises. This state is also so important for the businesses to survive in the existing conditions. Especially, as the hotel companies operate in the service sector and to take place within the tourism sector where economic impacts are fast, it is necessary that the hotel companies keep up with technological changes and have a qualified workforce, and it requires paying the same importance to human resources in order to be able to talk about quality. Because the use of all the possibilities of the technology in the hotel enterprises does not show that the comfort and the quality of the products are provided with the full service. The features such as "the ideas of this human resource, their point of view to the events, the ability to be practicality and regularity, the ability to solve problems, the contributions they make to the business when necessary conditions are given, the ability to perceive the change and apply these changes, the ability to express them well and self-confidence and the ability to notice in advance" have a vital pre-requisite for hotel business. As a matter of fact, hotel management employees are also required to perform their duties within the conditions necessary to achieve the aims and objectives. For that reason, it is clear that employees in businesses where working conditions are favorable may exhibit organizational citizenship behavior over time, which is a form of positive behavior.

Compared with the recent studies carried out on organizational citizenship behavior examined in this study, similar results have been achieved. Indeed, it is evident that organizational citizenship behavior has positive effects on managers and employees in hotel businesses. 
According to the results of the employees' perceptions of sub-dimensions of organizational citizenship behavior, the expression with the highest rate in the altruism dimension is "I allocate the required time to help people who have problems during work" while the expression with the lowest rate is "I help the newly started employee to learn the job". In addition to that, the expression with the highest rate in the conscientiousness dimension was found to be "I would like to participate in all the activities that will create a positive image for the organization I work for" whereas the expression with the lowest rate was found as "I spend most of my time in business related activities". On the other hand, the expression with the highest rate in the courtesy dimension is "I warn other employees not to be hurt when unexpected problems occur" while the expression with the lowest rate was detected as "I respect other people's rights and law". Also, in the sportsmanship dimension, the expression with the highest rate of organizational citizenship behavior is "I try to see the positive sides of the events, rather than focusing on problems related to the business environment" and the expression with the lowest rate was found as "I do not feel embarrassed or resentful about new situations I have experienced at work". Finally, the expression with the highest rate of organizational citizenship behavior in the Civic Virtue dimension was detected as "I keep up with the changes made in the structure of the organization I work with" whereas the expression with the lowest ratio was figured to be "I take part in research and project groups that perform all kinds of developing activities".

According to the organizational citizenship behavior model of structural equation (Figure 1), there is a positive and meaningful relationship between the dimension of the altruism dimension and the conscientiousness and between sportsmanship and civic virtue dimensions in increase of one unit. Also, it was also found that there is a negative relationship with the courtesy dimension. It has been found that there is a significant relationship between the dimension of conscientiousness and courtesy and between the dimension of sportsmanship and civic virtue. It was observed that when one unit of increase is made in courtesy and sportsmanship and civic virtue dimensions, meaningful relationships in the positive direction were achieved. In this context, it is seen that the dimensions of the organizational citizenship behavior have positive effects among each other when hotel management employees display the organizational citizenship behavior.

The study found that hotel employees' perceptions of organizational citizenship behaviors are positive. Employees seem ready to make a contribution to the goals of hotel businesses when the necessary working environment and conditions are met. In this context, it is also revealed that steps can be taken to create a positive work environment in which employees are allowed to use their capacities at advanced levels and to solve problems, to set policies for their working environment, to determine policies for their own working environment, to decide; and all employees are included in this process. 
This study was performed in order to examine the reciprocal impact scores of the level of organizational citizenship behavior and the organizational silence of the employees in the hotel businesses operating in the province of Rize in the Black Sea Region of Turkey through structural equation model. In this context, it is possible to list the research suggestions that will be useful for future consideration of researchers who will conduct research on the subject as follows:

This research was conducted on employees of five-star hotel businesses in Rize. That is to say, there is a need for studies to examine the organizational citizenship behavior in other tourism businesses and other destinations or regions. This study is of importance to the destinations or regions where tourism movements are beginning to intensify and develop, such as Rize Province. This is because they may enable practitioners to use this study a reference to compare with other business types.

Researches to be carried out in accordance with the needs, ideas and expectations of the hotel employees may serve fruitful results for service businesses in the long-term. Therefore, a working environment will be created in which appropriate conditions are provided for the employees, their ideas are given importance, solutions are made to their problems, and the duties are fully fulfilled.

Especially, once the hotel managers have knowledge about these perceptions and behaviors, they could be aware of the fact that how these organizational citizenship behaviors could be achieved more in their businesses and they would know that they be active in achieving them.

It is natural that there are some limitations and incomplete sides of this study. However, this study also closes an important gap in the literature as it approaches the problem in respect to its sub-dimensions of organizational citizenship behavior. In the future it will be appropriate to carry out similar studies in this regard, especially with different sample sizes. Performing similar studies in different sectors will allow us to better understand organizational citizenship behavior and will allow the practitioners to follow strategies that can change employees' behaviors in a positive way.

\section{References}

[1] Gürbüz, S. (2006) Örgütsel Vatandaşlık Davranışı ile Duygusal Bağlllık Arasındaki İlişkilerin Belirlenmesine Yönelik Bir Araştırma. Ístanbul Üniversitesi İktisadi ve İdari Bilimler Fakültesi Ekonomik ve Sosyal Araştırmalar Dergisi, 3, 48-75.

[2] Mercan, M. (2006) Öğretmenlerde Örgütsel Bağl1lık Örgütsel Yabancılaşma ve Örgütsel Vatandaşlık, (Yayımlanmamış Yüksek Lisans Tezi). Afyon Kocatepe Üniversitesi Sosyal Bilimler Enstitüsü, Afyonkarahisar.

[3] İşbaşı, J.Ö. (2000) Çalışanların Yöneticilerine Duydukları Güvenin ve Örgütsel Adalete İlişkin Algılamalarının Örgütsel Vatandaşlık Davranışının Oluşumundaki Rolü: Bir Turizm Örgütünde Uygulama. (Yayınlanmamış Yükseklisans Tezi). Akdeniz Üniversitesi, Antalya.

[4] Püsküllüoğlu, A. (2000) Arkadaş Türkçe Sözlük, Arkadaş Yayınevi, Ankara.

[5] George, Ve Brief, J.M. and Arthur, P. (1992) Feeling Good-Doing Good : A Con- 
ceptual Analysis of the Mood at Work-Organizational Spontaneity Relationship. Psychological Bulletin, 112, 310-329. https://doi.org/10.1037/0033-2909.112.2.310

[6] Greenberg, J. and Baron, R.A. (2000) Behavior in Organizations. 7th Edition,: Prentice-Hall, Newjersey.

[7] Abu Tayeh, B. (2012) The Effect of Organizational Justice on Organizational Citizenship Behavior in Government Ministries Centers in Jordan. Islamic University Economic and Administrative Studies Journal, 20, 145-186.

[8] Organ, D.W. (1988) Organizational Citizenship Behavior: The Good Soldier Syndrome. Lexington Books, Lexington.

[9] Aslan, G. (2009) Karizmatik Liderlik ve Örgütsel Vatandaşlık Davranışı İlişkisi: "Kurumda Çalışma Yılı" ve "Ücret” Değişkenlerinin Rolü. Uluslararası Ínsan Bilimleri Dergisi, 6, 256-275.

[10] Graham, J.W. (1991) An Essay on Organizational Citizenship Behavior. Employee Responsibilities and Rights Journal, 4, 249-270. https://doi.org/10.1007/BF01385031

[11] Williams, L.J. and Anderson, S.E. (1991) Job Satisfaction and Organizational Commitment as Predictors of Organizational Citizenship and İn-Role Behaviors. Journal of Management, 17, 601-617. https://doi.org/10.1177/014920639101700305

[12] Van Dyne, L., Graham, J.W. and Dienesch, R.M. (1994) Organizational Citizenship' Behavior: Construct Redefinition, Measurement, and Validation. Academy of Management Journal, 37, 765-802. https://doi.org/10.2307/256600

[13] Yılmaz, K. (2010) Kamu Ortaöğretim Okulu Öğretmenlerinin Örgütsel Vatandaşlık davranışları İle İlgili Görüşleri. Ondokuz Mayıs Üniversitesi Eğitim Fakültesi Dergisi, 29, 1-16.

[14] Arslantaş, C. and ve Pekdemir, I. (2007) Dönüşümcü Liderlik, Örgütsel Vatandaşlık Davranışı ve Örgütsel Adalet Arasındaki İlişkileri Belirlemeye Yönelik Görgül Bir Araştırma. Sosyal Bilimler Dergisi, 1, 261-286.

[15] Güler, N. (2013) Üniversite Çalışanlarında Örgütsel VatandaşlıkDavranışı: Gazi Üniversitesinde Bir Araştırma. Gazi Üniversitesi, Ankara.

[16] DiPaola, M.F. and Hoy, W.K. (2005) School Characteristics That Foster Organizational Citizenship Behavior. Journal of School Leadership, 15, 387-406.

[17] Özkalp, E. (2003) Örgütsel Davranış. Eskişehir: Anadolu Üniversitesi Yayın No: 1468 Açıköğretim Fakültesi Yayın No: 782.

[18] Podsakoff, M.P., MacKenzie, B.S., Moorman, H.R. and Fetter, R. (1990) Transformational Leader Behaviors and Their Effects on Followers' Trust in Leader, Satisfaction, and Organizational Citizenship Behaviors. Leadership Quarterly, 1, 107-142.

[19] Özyer, K., Orhan, U. and Dönmez Orhan, D. (2012) Demografik Özelliklerin Örgütsel Vatandaşlık Davranışının Alt Boyutları İle İlişkisi: Bankacılık Sektöründe Bir Uygulama, Dokuz Eylül Üniversitesi İktisadi ve İdari Bilimler Fakültesi Dergisi, Cilt:27, Sayı:1, Y11:2012, ss.181-204.

[20] Mackenzie, S.B., Podsakoff, P.M. and Richard, F. (1993) The Impact of Organizational Citizenship Behavior on Evaluations of Salaesperson Performance. Journal of Marketing, 57, 70-80. https://doi.org/10.2307/1252058

[21] Yücel, G.F. (2006) Öğretmenlerde Mesleki Tükenmişlik ve Örgütsel Vatandaşlık Davranışı, (Yüksek Lisans Tezi) Afyonkarahisar: Afyon Kocatepe Üniversitesi Sosyal Bilimler Enstitüsü.

[22] Altaş, S.S. and Çekmecelioğlu, H.G. (2007) “İş Tatmini, Örgütsel Bağlllık ve Örgütsel 
Vatandaşlık Davranışının İş Performansı Üzerindeki Etkileri: Bir Araştırma. Öneri Dergisi, 7, 47-57.

[23] Özdevecioğlu, M. (2003) Örgütsel Vatandaşlık Davranışı ile Üniversite Öğrencilerinin Bazı Demografik Özellikleri ve Akademik Başarıları Arasındaki İlişkilerin Belirlenmesine Yönelik Bir Araştırma. Erciyes Üniversitesi İktisadi ve İdari Bilimler Fakültesi Dergisi, 20, 117-135.

[24] Keskin, S. (2005) Öğretmenlerde Çalışma Değerleri ve Örgütsel Vatandaşlık, (Yayımlanmamış Yüksek Lisans Tezi) Afyonkarahisar: Afyon Kocatepe Üniversitesi Sosyal Bilimler Enstitüsü.

[25] Podsakoff, M.P., Mackenzie, B.S., Paine, B.J. and Bachrach, G.D. (2000) Organizational Citizenship Behaviors: A Critical Review of the Theoretical and Empirical Literature and Suggestions for Future Research. Journal of Management, 26, 513-563. https://doi.org/10.1177/014920630002600307

[26] Elçi, M. (2005) Örgütlerde Etik İklimin Personelin Vatandaşlık Davranışlarına Etkileri, (Doktora Tezi). Gebze Yüksek Teknoloji Enstitüsü, Sosyal Bilimler Enstitüsü, Kocaeli.

[27] Şimşek, Ö.F. (2007) Yapısal Eşitlik Modellemesine Giriş Temel İlkeler ve LISREL Uygulamaları. Ekinoks, Ankara.

[28] Çelik, H.E. (2009) Yapısal Eşitlik Modellemesi ve Bir Uygulama: Genişletilmiş Online Alışveriş Kabul Modeli, (Doktora Tezi). Eskişehir Osman Gazi Üniversitesi Fen Bilimleri Enstitüsü, Eskişehir.

[29] Şahin, A., Cankurt, M., Günden, C. and Miran, B. (2008) Çiftçilerin Risk Davranışları: Bir Yapısal Eşitlik Modeli Uygulaması. Dokuz Eylül Üniversitesi İktisadi ve Ídari Bilimler Fakültesi Dergisi, 23, 153-172.

[30] Sümer, N. (2000) Yapısal Eşitlik Modelleri: Temel Kavramlar ve Örnek Uygulamalar. Türk Psikoloji Yazıları, 3, 49-73.

[31] Yılmaz, V. and Çelik, H.E. (2005) Bankacılık Sektöründe Müşteri Memnuniyeti ve Bankaya Bağlılık Arasındaki İlişkinin Yapısal Eşitlik Modelleriyle Araştırılması. 7 th Ulusal Ekonometri ve İstatistik Sempozyumu, İstanbul, 26-27 Mayıs 2005, 1-9.

[32] Rize İl Kültür Turizm Müdürlügü (2016). http://www.rizekulturturizm.gov.tr

[33] Basım, N.H. and Şeşen, H. (2006) Örgütsel Vatandaşlık Davranışı Ölçeği Uyarlama ve Karşılaştırma Çalışması. Ankara Üniversitesi Siyasi Bilimler Fakültesi Dergisi, 61, 83-101.

[34] Vey, M.A. and Campbell, J.P. (2004) ln.Role or Extra.Role Organization al Citizenship Behavior: Which Are We Measuring? Human Performance, 17, 119 135. https://doi.org/10.1207/S15327043HUP1701 6

[35] Williams, S. and Shraw, W.T. (1999) Mood and Organizational Citizenship Behavior: The Effects Ofpositive Affect on Employee Ocb Intentions. The Journal of Psychology, 133, 656-668. https://doi.org/10.1080/00223989909599771

[36] Turizm Bakanlığı (1989) Otelcilik ve Turizm Endüstrisinde İşgücü Araştırması. Turizm Bakanlığı Yayınları, Ankara.

[37] Ağaoğlu, O.K. (1992) İşgücünü Verimli Kullanma Tekniklerinin Turizm Sektörüne Uygulanması. andrimlilik Dergisi, 1, 110-121.

[38] Özdamar, K. (2001) Paket Programlar ve İstatistiksel Veri Analizi (Çok Değişkenli Analizler). (4. Baskı), Kaan Yayınları, Eskişehir.

[39] Sökmen, A. and Boylu, Y. (2011) Örgütsel Vatandaşlık Davranışı Cinsiyete Göre Farklılık Gösterir mi? Otel İşletmeleri Açısından Bir Değerlendirme. Gaziantep Üniversitesi Sosyal Bilimler Dergisi, 10, 147-163. 
[40] Alioğulları, Z.D. (2012) Örgütsel Sessizlik ve Örgütsel Vatandaşlık Davranışı Arasındaki İlişki: Bir Uygulama, (Yayımlanmamış Yüksek Lisans Tezi). Atatürk Üniversitesi Sosyal Bilimler Enstitüsü, Erzurum.

[41] Karaaslan, A., Ergun Özler, D. and Kulaklığlu, A.S. (2009) Örgütsel Vatandaşlık Davranışı Ve Bilgi Paylaşımı Arasındaki İlişskiye Yönelik Bir Araştırma. Afyon Kocatepe Üniversitesi, İ.İ.B.F. Dergisi (C.X I,S II, 2009), 135-160.

[42] Kalkan, A. (2013) Algılanan Örgüt Kültürünün Örgütsel Vatandaşlık Davranışı Üzerindeki Etkisi: Kuramsal ve Görgül Bir Araştırma, (Doktora Tezi). Selçuk Üniversitesi Sosyal Bilimler Enstitüsü, Konya.

[43] Aksoy, E.Ş. (2010) İşyerlerinde Mobingile Örgütsel Vatandaşşlık Davranışı Arasındaki İlişkinin İncelenmesine Yönelik Bir Araştırma. Dumlupınar Üiversitesi, SosyalBilimlerEnstitüsü, İşletme Anabilim Dalı, Kütahya.

[44] Baran, M. (2002) İşletmelerde Bilginin Yönetilmesi Ile Ilgili Olarak Geliştirilen Modeller Ve Bir Araştırma. İstanbul Üniversitesi SBE, Yayımlanmamış Doktora Tezi, İstanbul.

[45] Waris, R.G. (2005) An Examination of Organizational Culture, Employee Attitudes, and Organizational Citizenship Behaviors: A Path Analysis Approach. Umi, Kansas City.

[46] Aras, M. (2010) Örgütsel Bağlılık; GOÜ Akademik Personeli Üzerine Bir Uygulama, Yayınlanmamış Yükseklisans Tezi. Gazi Osman Paşaüniversitesi, Sosyal Bilimler Enstitüsü, Tokat.

[47] İşsever, H., Söyük, S. and Şengün, H. (2016) Kamu Hastanelerinde Çalışan Hemşirelerde Örgütsel Vatandaşlık Davranışı. Nobel Medicus, 12, 29-38.

[48] Uğurlu, C.T. and Demir, A. (2016) Örgütsel Vatandaşlık Davranışının Öncülü Olarak Okul Yöneticilerinin Kullandıkları Güç Kaynakları. Elektronik Sosyal Bilimler Dergisi, 15, 98-119. https://doi.org/10.17755/esosder.18275

[49] İpek, C. and Saklı, A.R. (2012) Çay Sektöründeki Kamu Çalışanlarının Örgütsel Kültür ve Örgütsel Vatandaşlık Davranışı Algıları. Ege Akademik Bakış, 12, 251266. https://doi.org/10.21121/eab.2012219539

\section{Submit or recommend next manuscript to SCIRP and we will provide best service for you:}

Accepting pre-submission inquiries through Email, Facebook, LinkedIn, Twitter, etc. A wide selection of journals (inclusive of 9 subjects, more than 200 journals)

Providing 24-hour high-quality service

User-friendly online submission system

Fair and swift peer-review system

Efficient typesetting and proofreading procedure

Display of the result of downloads and visits, as well as the number of cited articles

Maximum dissemination of your research work

Submit your manuscript at: http://papersubmission.scirp.org/

Or contact ib@scirp.org 